\title{
Molecular detection of Trypanosoma theileri and a new Trypanocidal drug, a review
}

\author{
Tewodros FENTAHUN \\ Unit of Biomedical Sciences, College of Veterinary Medicine and Animal Sciences, University of Gondar, P.O.Box 196, Gondar, Ethiopia \\ Corresponding author's Email: tedyvet@gmail.com; (D) ORCID: 0000-0002-2955-5638
}

\begin{abstract}
Introduction. Trypanosoma theileri (T.theileri) is apathogenic, cosmopolitan and commensal protozoa of cattle. Despite apathogenic in healthy, but not in stressed cattle; it's getting recent attention as a tool to tackle pathogenic ones. These days, researchers are giving due attention to study the biology and feasibility of T.theilerito use it as a model candidate for novel drug discovery. In addition, in-silico analysis using common antitrypanosome drug targets couldn't show significant similarity both at DNA and protein level. Nevertheless, homologous sequences have been identified among drug targets for Ornithine decarboxylase. This indicated the possibility to consider T.theileri as a model to search novel drugs once having whole genome sequences. The SDM 79 is an appropriate medium to cultivate at $26{ }^{\circ} \mathrm{C}$, without $\mathrm{CO}_{2}$. Gradient PCR amplification has been used to detect using T. theileri. The specific primer (Tth625) which reveals $465 \mathrm{bp}$ amplification product and also the full length $18 \mathrm{~S}$ ribosomal DNA sequence of T.theileri DNA detectable at 730 base pairs are commonly used. Whole genome and transcriptome analysis can show the phylogenetic relationship between T.theileri and other pathogenic Trypanosomes which can be the basis for novel drugs development. Aim. The purpose of this paper is toreview the nature of Trypanosoma theileri, its molecular identification and also using its apathogenic nature as an opportunity to discover anew Trypanocidal drug.
\end{abstract}

\author{
Original Article \\ PII: S225199392000005-10 \\ Rec. 11 March 2019 \\ Rev. 15 May 2019 \\ Pub. 25 May 2020 \\ Keywords \\ Model, \\ Novel Trypanocidal drug, \\ PCR, \\ SDM 79, \\ Trypanosoma theileri
}

\section{INTRODUCTION}

The Trypanosomatid parasites cause one of the most notorious human and animal Trypanosomiasis throughout Africa and South America.Even if trypanosomes are core causes of human (Sleeping sickness) and animal (Nagana) diseases, many other species are non-pathogenic [1]. Such apathogenic trypanosomatids are found worldwide, infecting a wide range of hosts. Among these, Trypanosoma theileri (T.theileri), is the one which is a ubiquitous, 'truly cosmopolitan' protozoan commensal of cattle found worldwide [1-3]. It was first described in cattle by Theiler, Laveran and Bruce in 1902 [4].

Natural infection can be found throughout all age of cattle though rare for those under a year old. Neither its life cycle nor host relationship is fully understood within the mammalian host. The principal vector(s) responsible for transmission of the parasite is Tabanidae. However, ticks (Hyalomma anatolicum and Boophilus microplus) have been also reported as a vector later [5]. It is typically characterized by stercorarian type of transmission [5]. Following ingestion of infected blood meal, trypanosomes develop in the hindgut of the vector, infection is then transmitted to new hosts through fecal contamination on mucus membrane or through skin abrasions [6]. In newly infected host, the epimastigotes multiplies in the bloodstream by binary fission. Besides, epimastigotes and large trypomastigotes in peripheral blood, flagellates have been also found in extravascular sites of lymph nodes, kidney, spleen and brain [6].

As a result of low parasitemia, the parasite is rarely detected during microscopic examination of the stained smears of peripheral blood; rather it lives for many years without being detected by such routine diagnostic technique [7]. Nevertheless, it can be detected by culturing peripheral blood using in vitro techniques. In order to isolate pathogenic African Trypanosomes, a kit called KIVI (Kit for In Vitro Isolation of trypanosome) was designed [8]. Similarly, Verloo et al. [2] proved that this kit can be used as an excellent tool to isolateT.theileriwith a much highersensitivity than the Roswell Park Memorial Institute medium (RPMI). On the other hand, there was evidence which endorsed the growth in RPMI medium easily [3]. However, the easier growth of T.theileri might reduce its efficiency to isolate pathogenic African Trypanosomes [2]. Furthermore, 
Hoare [4] reported that epimastigote form was grown 60 times more in cell culture media at $25^{\circ} \mathrm{C}$ than in blood agar media. A similar study in baby hamster kidney (BHK) cell culture inoculated with non-thrown blood buffy coat showed a typical morphological characteristics of T.theileri [3].

The current drugs available to treat Trypanosomiasis are not satisfactorybecause they cause significant public health problem with toxic side effects and have poor efficacy [9]. Among these drugs, Pentamidine, Diminazeneaceturate (Berenil), Isometamidium chloride (Samorin), and Ethidium bromide, are important antitrypanosomal drugs [10] Thus, there is an urgent need for new, improved antitrypanosomal drugs by relaying on the non-pathogenic T.theileri as a tool.

High-throughput screening (HTS) and virtual screening are used as a standard tool in drug discovery to identify novel lead compounds that target a biomolecule of interest. However, the latter is considered as a costeffective tool [11, 12]. Trypanosomatid RNA editing can be used to identify drug target for protozoan parasites which are causing diseases like Trypanosomiasis. Amaro et al. [13] reported that RNA-editing ligase-1 (REL-1) can be used as drug-like inhibitors of a key enzyme in the editing Machinery. Identification of inhibitors was done through a strategy employing molecular dynamics to account for protein flexibility [13]. Currently, new parasitic inhibitors have been identified due to the availability of automated high content microscopy approach [14].

For a better pharmacology hypothesis and tests, the development of computational (In Silico) methods is also playing a significant role. This method comprises pharmacophores, databases, quantitative structureactivity relationships, homology models and other molecular modeling approaches, machine learning, network analysis tools and data analysis tools that use a computer. These are primarily used alongside the generation of in vitro data both to create the model and to test it. Such models have seen frequently used in the discovery and optimization of novel molecules with affinity to a target, the clarification of absorption, distribution, metabolism, excretion and toxicity properties as well as physicochemical characterization [11].

Genome sequence analysis is used to find out molecules which are responsible for controlling parasite's pathogenicity, virulence, immunity and chemotherapeutics responses. Genetic analysis is vital to characterize targets for defining the degree of variation within a gene encoding an identified molecule as a potential drug target [15] At present, for organisms with known genome sequence, the search for these molecules are undergone through the application of bioinformatics, which enhances the speed with which genes, can be identified. Further challenges remain in bioinformatics-based screening of compounds from predicted protein structure and the computerized docking of small molecules onto these structures as a means for high throughput screening of lead targets. Although the algorithms underlying these programs have improved significantly, the predictions are imperfect [15]. There are plenty of challenges for the development of tools for a trypanosome vaccine, new therapeutics or specific diagnostics. Genome sequence data, differential gene expression analysis and comparative genomics are playing significant role for identification of remarkable candidate of targets [15].

Though T.theileri is nonpathogenic naturally, but it can cause illness to stressed cattle. Moreover, little is known about the parasite so far. However, since recently, it has become area of interest by considering it as a tool and vector to treat the pathogenic microorganisms; particularly protozoan parasites. For instance, according to a report by Mott et al. [1], T. theileri can offer significant potential to target multiple infections by using as a novel vehicle to transport targeted vaccine antigens and other protein of interest, and also has a potential to deliver therapeutics including the lytic factor to protect cattle from trypanosomiasis [1]. Furthermore, mixed infection they cause with pathogenic trypanosome on same host (cattle), and the presence of homologous sequences with specific sequences of anti-trypanosome drug targets from pathogenic Trypanosomes may guide us to use this parasite as a model candidate for the development of novel drugs to treat the pathogenic Trypanosomes. Though T.theileri is nonpathogenic naturally, but it can cause illness to stressed cattle. Moreover, little is known about the parasite so far. However, since recently, it has become area of interest by considering it as a tool and vector to treat the pathogenic microorganisms; particularly protozoan parasites. Therefore, the main objective of this paper is to review the possible detection ways and the role of T.theileri in new Trypanocidal drug discovery.

\section{DISCUSSION}

\section{Taxonomy}

Trypanosomes are members of the Order Kinetoplastida; Family Trypanosomatidae and Genus Trypanosoma. Based on the site of the parasite's growth in the vector, they are further classified as Stercoraria 
and Salivaria type. Stercorarian trypanosomes develop in the hindgut of the vector, following ingestion of infected blood meal, and infection is transmitted to new host through fecal contamination [6]. Trypanosomes from bovids and cervids formed the clade T. theileri in phylogenetic trees, which corresponds to the type-species of the subgenus Megatrypanum, a taxon comprised solely of trypanosomes from ruminants [16, 17].

Today, molecular testing has shown the phylogenetically useful genes at the clade, lineage, and genotype levels, supporting at least six genotypes within the clade T. theileri [17]. Moreover, Hoar [4] reclassified all trypanosomes from cattle and buffalo as T. theileri. Nevertheless, , only cattle isolates should be considered synonyms of $T$. theileri, whereas all Megatrypanum isolates from species of Artiodactyla other than cattle, including those of other Bovidae spp. with the exception of isolates from goats and sheep, should be classified as T.theileri-like. Trypanosomes, morphologically similar to T. theileri have been identified at least 24 different species of ruminants. Besides T. theileri of cattle, only T. melophagium (sheep) and T. theodori (goat) are considered to be separate species occurring in Bovidae because experimental cross-infections have established their host restriction to vertebrate and invertebrate hosts. Similarly, the inability to infect bovids supports the separateness of the Cervidae trypanosomes T. cervi and T. mazamarum from T. theileri. The knowledge of most Megatrypanum spp. of any other order other than Artiodactyla is restricted to morphology of blood forms [18].

The sequencing of polymorphic internal transcribed spacer of ribosomal DNA (ITS rDNA), spliced leader (SL) and CATL genes disclosed two phylogenetic lineages, TthI and TthII, and five genotypes of T. theileri. Phylogenetic analysis clustered together all T. theileri isolates from cattle so far examined, from North and South America, Europe and Asia [16, 17, 19].

Table 1. Taxonomy of Trypanosomes in general.

\begin{tabular}{|c|c|c|c|}
\hline \multicolumn{3}{|c|}{ Classical classification [4] } & \multirow{2}{*}{ Clade classification [86] } \\
\hline Section & Subgenus & Species and subspecies & \\
\hline \multirow{11}{*}{ Salivaria } & & T. bruceibrucei & \multirow{11}{*}{$\begin{array}{l}\text { T. brucei (T. brucei and related species } \\
\text { mostly transmitted by tsetse flies) }\end{array}$} \\
\hline & & T. bruceigambiense & \\
\hline & Trypanozoon & T. bruceirhodesiense & \\
\hline & & T. evansi & \\
\hline & & T. equiperdum & \\
\hline & \multirow{3}{*}{ Nannomonas } & T. congolense & \\
\hline & & T. simiae & \\
\hline & & T. godfreyi & \\
\hline & \multirow{2}{*}{ Duttonella } & T. vivax & \\
\hline & & T. uniforme & \\
\hline & Pycnomonas & T. suis & \\
\hline \multirow{16}{*}{ Stercoraria } & & T. cruzi & \multirow{5}{*}{$\begin{array}{l}\text { T. cruzi (T. cruzi and related species } \\
\text { transmitted by triatomine bugs) }\end{array}$} \\
\hline & Schizotrypanum & T. cruzimarinkellei & \\
\hline & schizotrypanum & T. vespertilionis & \\
\hline & & T. dionissi & \\
\hline & \multirow{5}{*}{ Herpetosoma } & T. rangeli & \\
\hline & & T. lewisi & \multirow{4}{*}{$\begin{array}{l}\text { Rodent(presumably transmitted by } \\
\text { fleas) }\end{array}$} \\
\hline & & T. musculi & \\
\hline & & T. nabiasi & \\
\hline & & T. microti & \\
\hline & \multirow{7}{*}{ Megatrypanum } & T. theileri & \multirow{7}{*}{ Other Trypanosoma clades } \\
\hline & & T. melophagium & \\
\hline & & T. conorhini & \\
\hline & & T. minasense & \\
\hline & & T. pestanai & \\
\hline & & T. cyclops & \\
\hline & & T. theodori & \\
\hline- & - & $\begin{array}{l}\text { T. carassi, T. cobitis, T. granulosum, T. } \\
\text { sinipercea, T. ophiocephali, T. chelodinae, T. } \\
\text { nudigobii, T. blennidini, T. haploblephari, T. } \\
\text { boissoni, T. capigobii, T. semegalense, T. } \\
\text { murmanense, T. pleuronectidium, T. triglae, T. } \\
\text { rotatorium, T. ranarum, T. chattoni, T. binneyi, } \\
\text { T. therezieni, T. mega, T. neveulemairei, T. fallisi }\end{array}$ & $\begin{array}{l}\text { Aquatic(transmitted by insects and } \\
\text { leeches, also includes trypanosomes } \\
\text { of platypuses and aquatic tortoises) }\end{array}$ \\
\hline- & - & $\begin{array}{l}\text { T. avium, T. bennetti, T. corvi, T. culicavium, T. } \\
\text { gallinarum, T. polygranularis, T. anguiformis }\end{array}$ & $\begin{array}{l}\text { Avian(transmitted primarily by black } \\
\text { flies and hippoboscid flies) }\end{array}$ \\
\hline
\end{tabular}




\section{Morphology}

Morphology is the traditional taxonomic criterion for the classification of T.theileri and allied species, which trypanosomes that share large blood trypomastigotes, restricted mammalian hosts, worldwide distribution, lack of pathogenicity and contaminative transmission by tabanid or hippoboscid flies [4]. It has been used as the exclusive taxonomic criterion to classify trypanosomes in the subgenus Megatrypanum, whose members have the largest mammalian blood trypanosomes with a small kinetoplast situated very close to the nucleus. Species within this subgenus are defined based on their host restriction. According to morphology and to the assumption that Megatrypanum spp. are mammalian host-specific, or at least infective to very closely related species, all isolates from cattle have been classified as T. theileri. It has been considered as an independent trypanosome occurring in distinct species and or races of Bovidae or in different countries, resulting in considerable synonymy [17].

In general, T. Theileriis large in size $(25-120 \mu \mathrm{m})$ long with long-pointed posterior end (Figure 1$)$. The kinetoplast is large in size and has well developed undulating membrane and free flagellum. Both trypomastigote and epimastigote may occur in blood. Body is somewhat curved and is drawn to fine point at posterior end. Important character in this trypanosome is the possession of well-marked myonemes [17].

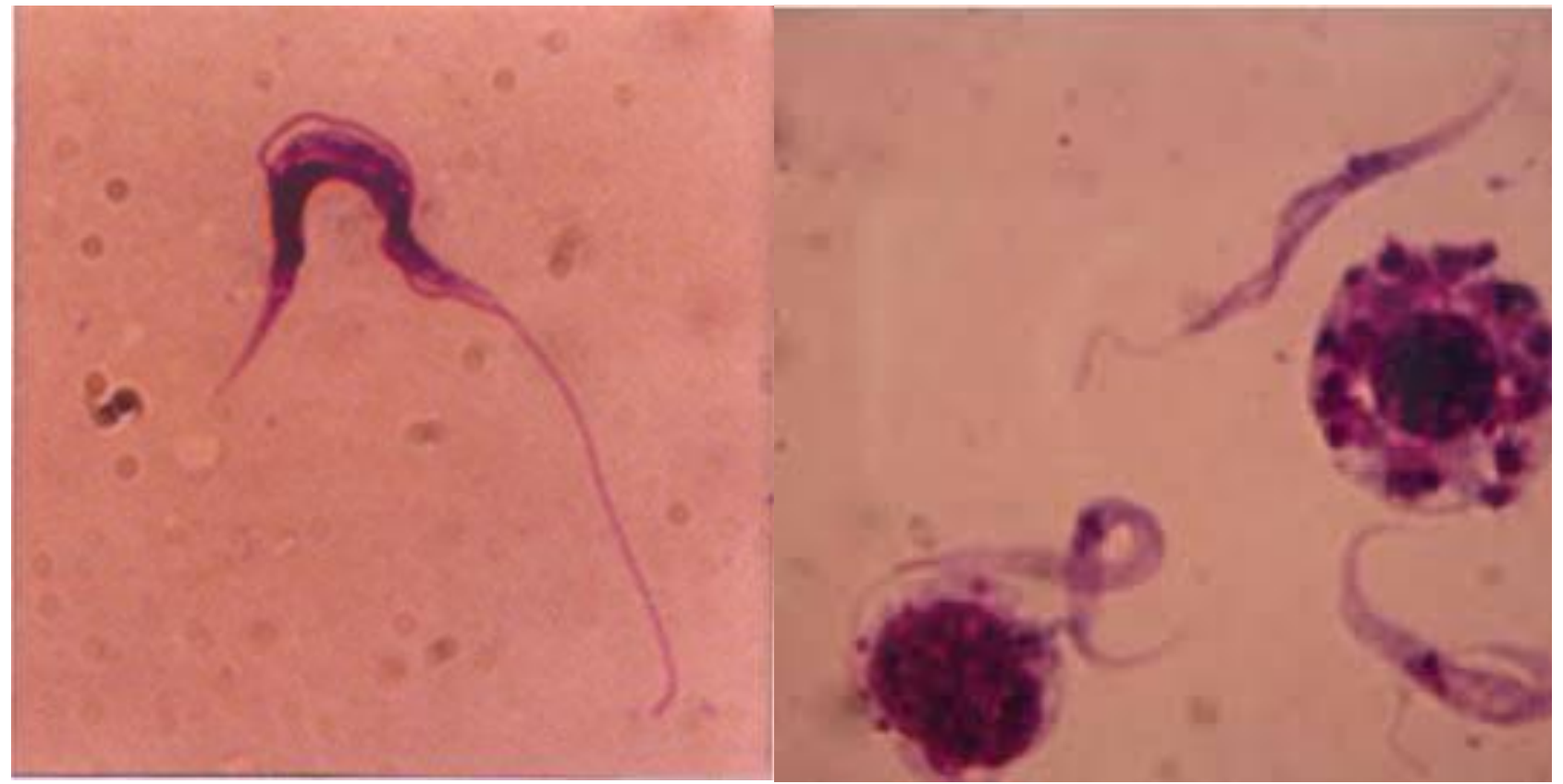

Figure 1. Photomicrograph of trypomastigotes found in blood-derived mononuclear cell cultures from different naturally infected cows, from San José del Nus, Antioquia, morphologically characterized as T. theileri [21].

\section{Epidemiology}

This species is a cosmopolitan parasite of cattle with high incidence on every continent except Antarctica $[4,16]$. There are numerous records of T. theileri in cattle. For example in Western Europe, T. theileri is the only trypanosome species occurring in cattle [2]. Hence, it has been reported in European countries (France, Germany, England, Scotland, Belgium, Italy and Spain), North America (USA, Canada), South America (Brazil) and Asia (Korea and Bangladesh) and Africa [2]. Besides cattle, morphologically indistinguishable trypanosomes related to T. theileri have been described in otherdomestic and wild artiodactyls, including buffalo, sheep, goat, antelopes, and cervids $[4,16]$.

\section{Vector}

A principal vector for T. theileri is Tabanidae (Diptera) flies, commonly known as horse flies, deer flies, clegs, or blind flies. Different species such as Haematopota pluvialis, Tabanus glaucopis and T. striatus were found as intermediate host experimentally [4]. It is among the nuisance pests for people and livestock because of their painful and irritating bite, persistent biting behavior, and blood ingestion. They are seasonally present in all kinds of landscapes, latitudes, and altitudes [22]. In addition, ticks can also maintain the development of T.theileri. A high infection rate of the tick with T. theileri was reported by Latif et al. [5]. Morzaria et al. [23] in the Sudan reported the first biological transmission of T. theileri to cattle by the tick, H. a. anatolicum. Asimilar study 
was done in Brazil showed that epimastigote forms were found in the hemolymph of the cattle tick Boophilus microplus in the state of Rio Grande do Sul, southern Brazil [24].

\section{Life cycle}

So far, the life cycle of T.theileriwithin mammalian host has rarely been reported $[3,22]$. It has an indirect life cycle and transmitted cyclically by tabanid. Trypanosomes undergo development in the hind gut of the tabanid flies $[4,25]$. Cattle are infected commonly though contamination of the mucous membrane with flies faeces containing the small metacyclic forms (Stercoraria) [25]. In vitro infections showed that transmission occurs by excretion of metacyclic form in tabanid feces, which gain entrance into a new host either by the bite wound of the vector or by skin abrasions. Furthermore, ingestion of feces or the vector itself by the host can cause infection $[26,25]$.

The parasite has several development stages (Figure 2). Epimastigotes undergo multiplication asexually by binary fissionin the lymph nodes and in various internal organs and in the bloodstream which is hardly detectable [19]. As epimastigotes and large trypomastigotes have been found in peripheral blood, flagellates are also found in extra-vascular sites of lymph nodes, kidney, spleen, and brain [27]. Based on the report by Bose et al. [26]; the infective stages were found in the hind hut and faeces of Tabanids. Although "amastigote-like" forms were described within bovine lymphocyte cultures, the existence of intracellular stages of T. theileri in tissues of vertebrates has not been reported [28].

A

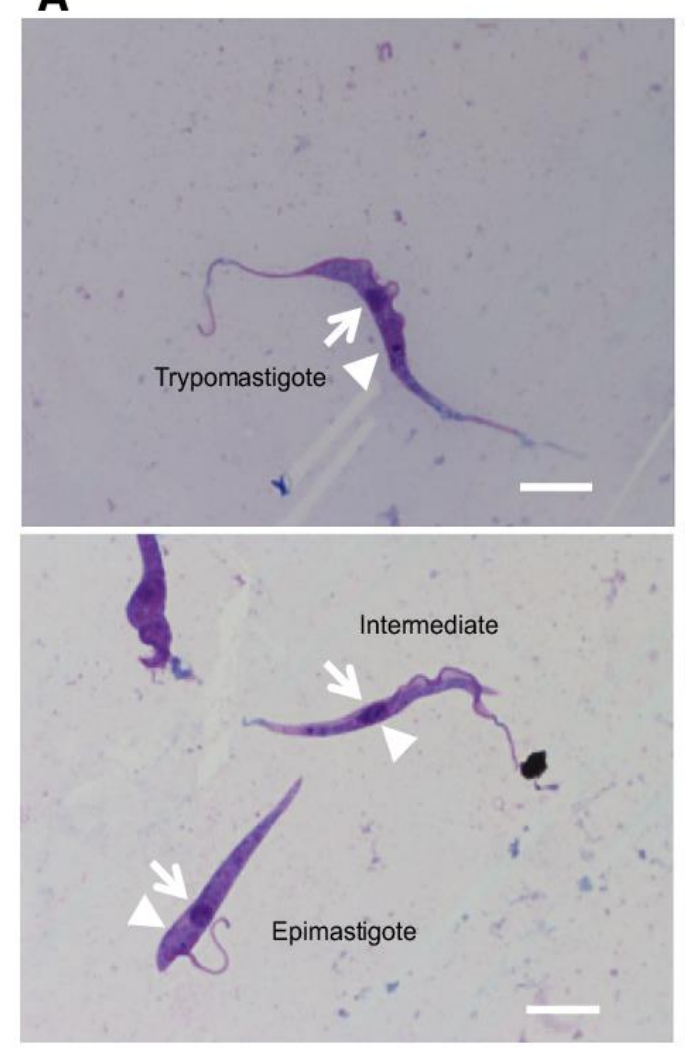

B
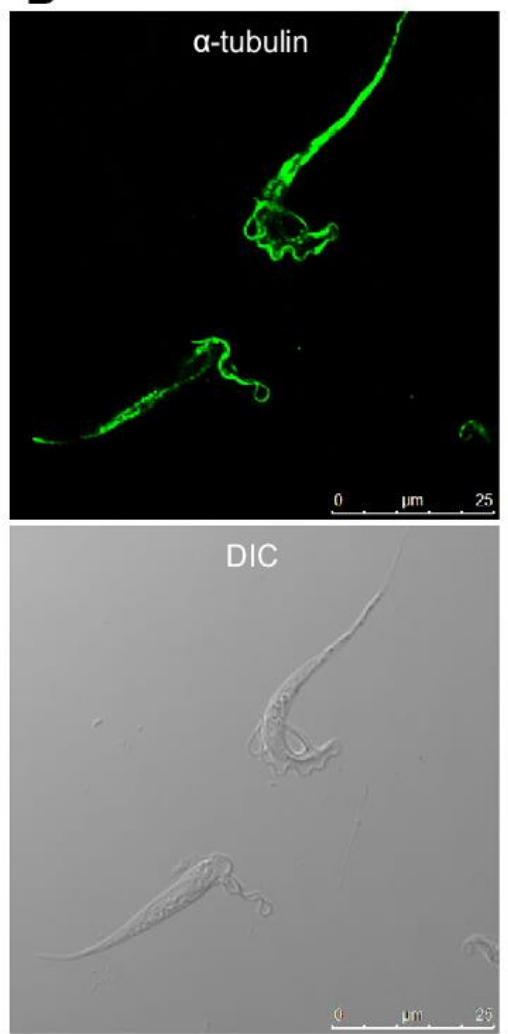
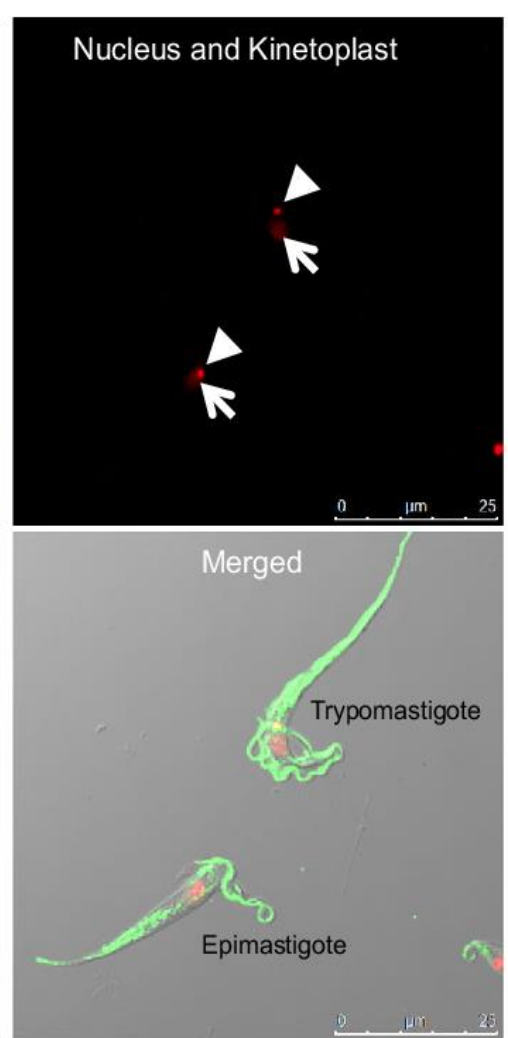

Figure 2. Morphological analysis of T.theileri. Images of Giemsa-stained T. theileri. The trypomastigote form (upper panel) and epimastigote and intermediate forms (lower panel) were observed under a microscope [29].

\section{Transmission}

Megatrypanum spp. are cyclically transmitted by Tabanid and transmission is contaminative [26, 25]. Furthermore, infection of $T$. theileri established in the calves with the Trypanosomatid flagellates from the tick H. a. anatolicum [30]. The transmission was contaminative by excrements containing metacyclictrypomastigotes. In the vertebrate host, the stercorarian trypanosomes multiply as amastigotes or epimastigotes. Trypomastigote stages found in the peripheral blood, do not divide and their sole function is to spread the infection into other organs and enable the transmission into the vector. T.theileri and T.melophagium are stercorarian species transmitted by tabanid and hipoboscid flies to cows and sheep, respectively [31]. 


\section{Pathogenesis}

Despite its nonpathogenicity, detectable parasitemia is usually associated with concomitant disease, suggesting that host immunity is involved in parasite control [32]. The parasiteinduces chronic and cryptic infections which is potentially pathogenic for those under severe physical and nutritional stress, for newborn and pregnant cows, and when associated with concurrent infectious diseases.Prolonged infection persists without any clinical signs. The depression of the immune system is thought to allow for increased parasitemia and dispersion of T. theileri through several organs including central nervous system [27, 33-35].

\section{Diagnosis and confirmation of T.theileri}

So far, the diagnosis of this species requires isolation by blood culture, which is a laborious, time consuming and expensive method. Although no serological diagnostic method has been developed specifically for $T$. theileri, a lack of cross-reactivity has been demonstrated for methods used to diagnose T. evansi, T. congolense, T. vivax and T. b. brucei [36]. Furthermore, T. theileri can be distinguished from other trypanosomes by PCRamplification of ITS rDNA, SL and CATL sequences $[16,17,37]$ Nevertheless, such molecular studies are limited by the low levels of parasitemia; by rare parasites in blood smears despite positive hemocultures [16, 17].

\section{a) Cell Culture}

Isolation of T.theileri from whole or defibrinated blood of infected cattle can be done in a variety of culture media. Though it is easier to isolate the organism, its continuous maintenance in culture is much more difficult. The presence of blood cells, the temperature of cultivation and the type of culture vessel used appear to be important [38]. Cultivation at room temperature results in multiplication in the crithidial stage, and only in a few instances has the organism been cultivated at $37^{\circ} \mathrm{C}$ in the trypanosome stage [39]. Attempts by Herbert [38] to obtain continuous culture of $\mathrm{T}$. theileri at $37^{\circ} \mathrm{C}$ were unsuccessful. Later, T.theileri in the trypanosome form has been reported as a contaminant in cultures, at $37^{\circ} \mathrm{C}$, of normal bovine fetal kidney cells or blood lymphocytes and lymph node cells of cattle with lymphatic leukemia or viral diarrhea. Tissue culture fluids, supplemented with newborn calf serum and blood or blood products, are suitable for the isolation and continuous cultivation of T.theileri at $37^{\circ} \mathrm{C}$ [39]. Cultivation of the trypanosomes at $37^{\circ} \mathrm{C}$ has been reported in non-defined or partially defined monophasic liquid media containing erythrocytes or erythrocyte products, in embryonal chicken eggs and in various types of cell cultures [40]. Furthermore, the KIVI culture systemhas been designed for the isolation of pathogenic African trypanosomes, particularly, T. Brucei gambiense which is found applicable for T.theileri too [8]. Similarly, Rosewell Park Memorial Institute (RPMI) based culture systems have been described for culturing bloodstream forms of T. b. brucei [41]. Hence, in an attempt to isolate a stock of T.theileri, blood samples can be inoculated into both RPMI 10\%+feeder and KIVI culture medium [2].

\section{b) Polymerase Chain Reaction (PCR)}

A large variety of molecular diagnostic testshave been developed for human and animal African trypanosomiasis based on detection of trypanosome DNA or RNA [42]. It can be applied on all biological specimens that may contain the parasite's nucleic acids such as blood, CSF, lymph node and chancre aspirate, biopsy and histological material. Even from stained microscopic slides, DNA can be extracted for subsequent PCR $[42,43]$. PCR allow discrimination of the trypanosome species in one single run and even in the same specimen in case of mixed infection. For instance, the 18S-PCR-RFLP where cleaving of the amplicon with two restriction enzymes generating fragment profiles that are characteristic for T. congolense, T. vivax, Trypanozoon and T. theileri (Table 6) [43]. Similarly, differential diagnosis can be obtained with the less complex ITS1 PCR which generates amplicons of taxon specific lengths [37, 44]. Species specific PCRs can be also hampered by genomic variation within the target taxon. According to Njiru [45], a Loop mediated isothermal amplification (LAMP) of DNA is a less demanding technology that may prove a real breakthrough in molecular diagnosis. In LAMP, DNA is amplified without prior heat denaturation and the amplicons are visualised by turbidimetry, colori metric reactions or fluorescence [46].

\section{c) Two-Dimensional Gel Electrophoresis (2-DE)}

After having sequenced whole genomes, better understanding of cellular mechanisms relies on studying the functional units of gene expression-proteins. Among these approaches in proteomicsis the use of twodimensional gel electrophoresis as a means of separation and visualization of complex protein mixtures extracted from biological samples. Despite several limitations of the method, its ability to separate large numbers of proteins, including their post-translationally modified forms, ensures that it will continue to be popular in several well-defined areas of proteomics $[47,48]$. Gene expression profiling is the survey of a large 
number of genes and/or their expression products, typically in an effort to identify differentially expressed genes, or broad patterns of gene expression under different experimental conditions. The utility of gene expression profiling for understanding molecular processes, elucidation of drug target interactions, clinical diagnosis, etc., cannot be overstated. Several DNA based methods for profiling of gene expression have been previously described [48]. Two-dimensional electrophoresis (2-D electrophoresis) is a powerful and popular technique to sort proteins based on two independent properties and discrete steps: the first-dimension step, isoelectric focusing (IEF), separates proteins according to their isoelectric points ( $\mathrm{pI}$ ); the second-dimension step, SDS-Polyacrylamide Gel Electrophoresis (SDS-PAGE), separates proteins according to their molecular weights. Each spot on the resulting two-dimensional array corresponds to a single protein species in the sample. Many different proteins can be separated, and information like $\mathrm{pI}$, apparent molecular weight, and the amount of each protein is obtained [49,50]. It has also a distinct capability to detect post- and co-translational modifications, which cannot be predicted from the genome sequence. Its applications include proteome analysis, cell differentiation, and detection of disease markers, monitoring therapies, drug discovery, cancer research, purity checks, and micro-scale protein purification. Furthermore, precast IPG strips are used (Immobiline Dry Strip gels) which is available from Amersham Biosciences [51].

\section{d) High Throughput Microscopy}

High-throughput microscopy (HTM) shows images which are generated automatically upon many different treatments for a certain period. This technology has opened the way to conduct large-scale, image-based screens to discover novel genes and their functions [52]. Now days, there are several commercially available platforms of high-content high-throughput microscopy. They consist a fully automated wide-field or confocal microscope with specialized hardware and software to manage large sets of information. They are equipped with state-of-the-art optics enabling a broad range of fluorescence excitation and multi-channel which enables to detect several spectrally distinct fluorophores parallelly. Such imaging platforms are capable of imaging at different magnifications, which assists in imaging of both large populations of cells or sub-cellular details in a group of selected cells [53]. For systematic analyses of protein function, quantitative fluorescence microscopy is now becoming one of the tools of choice in large-scale [54]. Compared to a non-microscopic screening approaches, fluorescence microscopy provides information at the single-cell or even sub-cellular level. It is enables an enhanced statistical data analyses for the identification of distinct phenotypic populations in one culture treated in similar way. On the other hand, Microscopic analyses can also be performed in living cells for extended periods of time to return vital data on the dynamics of fluorescent molecules [53,55], or the order of occurrence of phenotypes during the observation period [56]. Overall, to apply this technology, there are several steps and optimization involved in an experiment. These are sample preparation, image acquisition, image analysis, data storage and handling, data mining and modelling (Figure 3). Hence, it enables unsupervised data collection with high information content on the temporal and spatial distributions and states of fluorescent markers [54, 53].

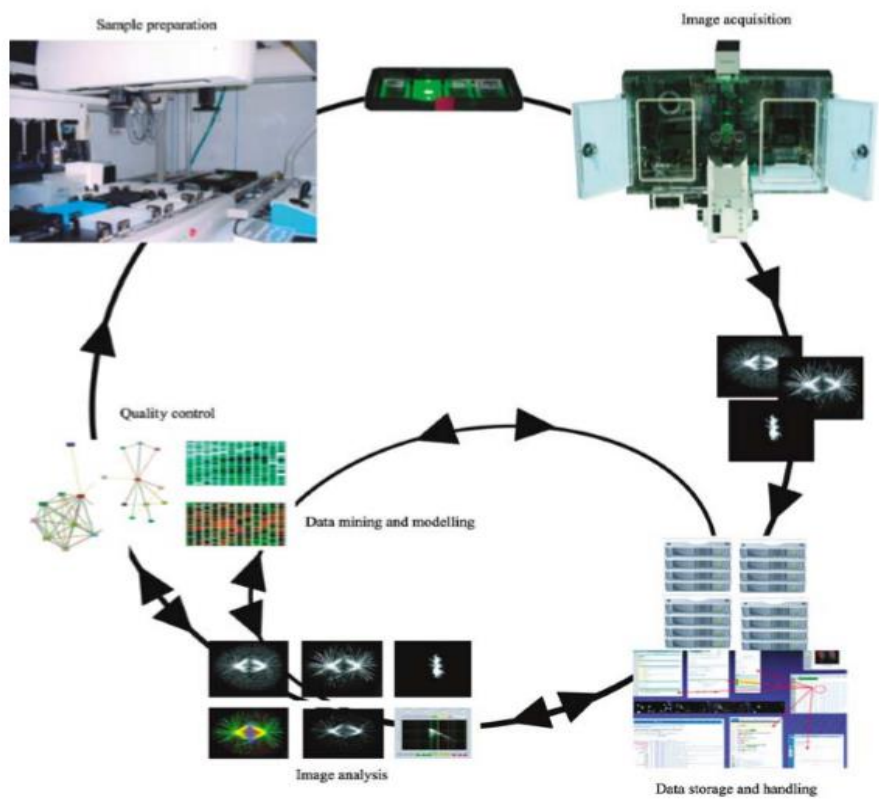

Figure 3. The principle: Steps in high-content high-throughput microscopy; adapted from Starkuviene and Pepperkok [53]. 


\section{Current state of therapy and recent developments}

The idea of specific chemotherapy was developed a century ago by Paul Ehrlich and others. Dyes and arsenical compounds that displayed selectivity against trypanosomes [57].

\section{Commonly used drugs to treat sleeping sickness}

Since half a century ago, we have been using only certain drugs to treat Human African Trypanosomiasis (HAT). There is a very limited arsenical drug with shortcomings such as high toxicity with emerging-resistance. Early stages of HAT are treated with pentamidine, an aromatic diamidine, and suramin, a naphtaline derivative. Adverse effects for these drugs are significant and the failure rate is high. Late stages of HAT are treated with Melarsoprol, a melaminophenyl arsenical compound that is able to cross the blood brain barrier [58]. Melarsoprol (Arsenicals) have been the most effective drugs universally to treat sleeping sickness despite resistance of trypanosomes and toxicity to patients. Side effects are severe and up to $5 \%$ of those treated die of drug-induced reactive encephalopathy [58]. On the other hand, Pentamidine, Suramin and Berenil ${ }^{\circledR}$ are active only in the first stage of the disease when the parasite is restricted to the blood and lymphatic circulatory system [36, 59]. However, neither of these compounds crosses the blood-brain barrier to treat central nervous system infections. On the contrary, Nifurtimox and alpha-difluoro-methylornithine provide interesting alternatives totreat the central nervous systeminfection. Nevertheless, DFMO is known to be less active against T.rhodesiense [6o].

Recently, eflornithine-nifurtimox combined therapy islaunchedand found the safest treatment for latestage trypanosomiasis [59]. This mixed drug allows significant reduction of eflornithine dose and treatment duration. However, like eflornithine alone, this combined therapy is only effective in the second stage of T. $b$. gambiense infections. This leaves melarsoprol which causes reactive encephalopathy in about $10 \%$ of treated patients, as the only effective drug against both T. b. rhodesiense and T. b. gambiense late-stage infections. Because of this, the increasing rate of melarsoprol treatment failures is alarming [61].

Table 2. Problems associated with current drugs for human African trypanosomiasis

\begin{tabular}{llll}
\hline S.No & Drug & Use & Problem \\
\hline 1. & Suramin & $\begin{array}{l}\text { Effective against early stage of T. } b . \\
\text { rhodesiense }\end{array}$ & $\begin{array}{l}\text { Ineffective against early stage of T. b. gambiense and late } \\
\text { stage of both HATs }\end{array}$ \\
\hline 2. & Pentamidine & $\begin{array}{l}\text { Effective against early stage of T. b. } \\
\text { gambiense }\end{array}$ & $\begin{array}{l}\text { Ineffective against early stage of T. b. rhodesienseand late } \\
\text { stage of both HATs }\end{array}$ \\
\hline 3. & Melarsoprol & Effective against late stage of both HATs & Toxic (kills up to 5\% of patients) Resistance observed in field \\
\hline 4. & Eflornithine & $\begin{array}{l}\text { Effective against late stage of T. b. } \\
\text { gambiense }\end{array}$ & $\begin{array}{l}\text { Ineffective against late stage of T. b. rhodesiense Difficult } \\
\text { dosing scheme, and cost of hospitalisation }\end{array}$ \\
\hline
\end{tabular}

Adapted from Wilkinson and Kelly [62].

\section{Commonly used drugs to treat animal trypanosomiasis}

These days, several chemotherapeutic agents have been used to treat animal trypanosomiasis. However, most of these have a narrow therapeutic index which makes administration of the correct dose essential. Drug resistance occurs and should be considered in refractory cases [63].

Table 3. Drugs commonly used for Trypanosomiasis in domestic animals

\begin{tabular}{llll}
\hline Drug & Animal & Trypanosoma & Main Action \\
\hline Diminazene Aceturate & Cattle & Vivax, congolense,brucei & Curative \\
\hline Homidium Bromide & Cattle, Equids & Vivax, congolense,brucei & Curative, some prophylactic activity \\
\hline Isometamidium Chloride & Cattle & Vivax, congolense & Curative and prophylactic \\
\hline Quinapyramine Sulfate & $\begin{array}{l}\text { Horses, camels, } \\
\text { pigs, dogs }\end{array}$ & $\begin{array}{l}\text { Vivax, congolense,brucei, evansi,equiperdum,si } \\
\text { miae }\end{array}$ & Curative \\
\hline $\begin{array}{l}\text { Quinapyramine } \\
\text { Dimethylsulfate }\end{array}$ & $\begin{array}{l}\text { Horses, camels, } \\
\text { pigs, dogs }\end{array}$ & $\begin{array}{l}\text { Vivax, congolense,brucei, evansi,equiperdum,si } \\
\text { miae }\end{array}$ & Prophylactic \\
\hline Suramin & $\begin{array}{l}\text { Horses, camels, } \\
\text { dogs }\end{array}$ & Brucei, evansi & Curative, some prophylactic activity \\
\hline $\begin{array}{l}\text { Melarsomine } \\
\text { Dichlorhydrate }\end{array}$ & Camels & Evansi & Curative \\
\hline Adapted from Cynthia et al. [63]. & &
\end{tabular}




\section{Mechanism of actions}

Arsenical drugs that are used to treat late-stage African trypanosomiasis kill cells sooner in lowdrugdosage. It results in oxidative stress via nonspecific covalent binding to thiol groups [64]. Whereas, Difluoromethylornithine (DFMO/Eflornithine) is a suicide inhibitor of ornithine decarboxylase [65]. Furthermore, Isometamidium is an ethidium bromide derivative which intercalates selectively in the kDNA. As a consequence, it affects the kDNA integrity by preventing networkdivision [66]. Pentamidine, Diminazeneaceturate (Berenil), Isometamidium chloride (Samorin), and Ethidium bromide, which are important antitrypanosomal drugs, promote linearization of Trypanosoma equiperdumminicircle DNA. This effect occurs at therapeutically relevant concentrations [10]. Having know-how on the mechanism of action of antitrypanosomal drug efficacy and resistance, will help us to develop a new therapeutic principle to combat drug resistance and contributes to have the idea on the mode of actions of anti-trypanosomal resistance at molecular level [14].

Now a day, there is a breakthrough of $T$. theileri which has been used as a novel vehicle to deliver vaccine antigens and other proteins to control pathogenic trypanosomatids [1]. Favorable conditions for the growth and transfection of $T$. theileri have been optimised and expressed heterologous proteins targeted for secretion or specific localisation at the cell interior or surface using trafficking signals. Engineered vehicle could establish in the context of a pre-existing natural T. theileri population, was maintained long-term and generated specific immune responses to an expressed Babesia antigen at protective levels. It also has the potential to deliver therapeutics to cattle, including the lytic factor which protects humans from cattle trypanosomiasis [1].

\section{Drug resistance}

Drug resistance is a major impediment in the treatment of the diseases given that existing drugs are old with severe side effects. Most resistance mechanisms developed by these parasites are related with a decreased uptake or increased efflux of the drug due to mutations or altered expression of membrane transporters. Different new approaches have been elaborated that can overcome these mechanisms of resistance including the use of inhibitors of efflux pumps and drug carriers for both active and passive targeting [61].

The two principal drugs, Melarsoprol and Pentamidine have been used to treat both sleeping sickness in humans and Nagana in livestock. However, since half a century ago, cross-resistance to these drugs was found and remains the only example of cross-resistance among sleeping sickness therapies. Adenosine transporter in T.brucei, is well-known for its role in the uptake of these drugs. Furthermore, aquaglyceroporin-2 (AQP2) lossof-functions was linked to melarsoprol-pentamidine cross-resistance. AQP2, a channel that appears to facilitate drug accumulation, may also be linked to clinical cases of resistance [67].

\section{Target sequences screening}

At the molecular level, the main targets for drugs are proteins (mainly enzymes, receptors and transport proteins) and nucleic acids [68]. Drugs bind to their corresponding targets and perform the desirable therapeutic effects. These days, the identified drug targets have been stored in databases such as DrugBank [69] Therapeutic Target Database (TTD), Potential Drug Target Database (PDTD) and TDR Targets Database [70, 71].

Searching for novel genes required for survival or virulence of any organism was based on several genetic methods involving genetic crosses, gene knockouts and induced mutations, followed by screening for the relevant phenotype. In trypanosomes, these approaches have been hampered by the inability to generate sufficient numbers of progeny clones from genetic crosses and the lack of a fine genetic map. These problems have affected the ability to determine precisely the statistical significance of segregating phenotypes in relation to the number of loci or alleles determining the trait of interest [72].

Current methods for target-based drug discovery usually involve screening diverse or focused libraries against the molecular target (Table 4). The hits are then characterized and optimized through rounds of design, synthesis and testing against protein and cell. The testing usually includes assays for potency, selectivity and pharmacokinetic properties. In terms of target validation, it is important to prove that the compounds are acting on-target for inhibition or modulation of the target that is causing the death of the parasite. The compounds are then assayed in animal models of infection. It is only at this stage that it becomes clear if the proposed drug target has a reasonable degree of validation. It shows that it takes both time and resource before getting evidences which shows the target chosen, is truly valid drug target. Therefore, it is important to choose drug targets very carefully at the outset of a drug discovery programme [9]. 
Elucidation of molecular targets is very important for lead optimization during the drug development process. A direct method to find targets of antitrypanosomal compounds against T.brucei using a trypanosome overexpression library was done by Begolo et al. [73]. As proof of concept, the library was treated with Difluoromethylornithine and DDD85646 and identified their respective targets, ornithine decarboxylase and Nmyristoyltransferase. The overexpression library could be a useful tool to study the modes of action of novel antitrypanosomal drug candidates [73].

RNA interference (RNAi) is a phenomenon through which double stranded RNA induces potent sequencespecific degradation of homologous transcripts. Besides its function in cellular defense and developmental regulation, it has emerged as an invaluable tool for elucidation of gene function and drug target validation. This is particularly useful when substantial genome sequence data are available. Gene silencing using RNAi can aid translation of raw genomic sequence data into biologically relevant information toward the development of new and/or improved control strategies [74].

Table 4. Common antitrypanosomal drug targets.

\begin{tabular}{|c|c|c|c|c|c|}
\hline & Drugs & Target & Accession No & Organism & Sources \\
\hline \multirow{3}{*}{1.} & \multirow{3}{*}{ Difluoromethylornithine } & \multirow{3}{*}{ Ornithine decarboxylase } & XM_824336 & T.bruceibrucei & \multirow{3}{*}{ Begolo et al. [73] } \\
\hline & & & AF042286 & T.bruceigambiense & \\
\hline & & & Jo2771 & T.brucei & \\
\hline \multirow{3}{*}{2.} & \multirow{3}{*}{ DDD85646 } & \multirow{3}{*}{ N-myristoyltransferase } & XM_822811 & T. bruceibrucei & \multirow{3}{*}{ Begolo et al. [73] } \\
\hline & & & XM_oog314999 & T.grayi & \\
\hline & & & HQ587038 & T.cruzi & \\
\hline 3. & $\begin{array}{l}\text { Pentamidine, } \\
\text { Diminazene and } \\
\text { Suramin }\end{array}$ & $\begin{array}{l}\text { Cytosolic serine Oligopeptidase } \\
\text { (OP-Tb) }\end{array}$ & XP_009306351 & T.grayi & Rory et al. [75] \\
\hline 4. & Proteasome inhibitors & $\begin{array}{l}\text { Trypanosomal proteasome } \\
\text { exhibiting high trypsin-like but } \\
\text { low chymotrypsin-like } \\
\text { activities }\end{array}$ & - & T. bruceibrucei & $\begin{array}{l}\text { Dietmar and } \\
\text { Kevin [76] }\end{array}$ \\
\hline \multirow{7}{*}{5.} & \multirow{7}{*}{$\begin{array}{l}\text { Cysteine protease } \\
\text { inhibitors, Peptidyl } \\
\text { inhibitors and Non- } \\
\text { peptidyl inhibitors) }\end{array}$} & & XM_009318006 & T.grayi & \multirow{7}{*}{$\begin{array}{l}\text { Dietmar and } \\
\text { Kevin [76] }\end{array}$} \\
\hline & & & GU299414 & T.theileri & \\
\hline & & Cathepsin L-Like Cysteine & GU299413 & T.theileri & \\
\hline & & Protease (Brucipain and & GU299412 & T.theileri & \\
\hline & & Cruzipain) & GU299411 & T.theileri & \\
\hline & & & GU299410 & T.theileri & \\
\hline & & & XP_009316281. & T.grayi & \\
\hline \multirow{11}{*}{6.} & \multirow{11}{*}{ Pyruvate kinase } & & CAA44870.1 & T. brucei & \multirow{11}{*}{ NCBI database } \\
\hline & & & XP_009309990 & T. grayi & \\
\hline & & & KEG11772.1 & T. grayi & \\
\hline & & & ORC92589.1 & T.theileri & \\
\hline & & & CAA41018.1 & T. brucei & \\
\hline & & & 3QV9_B & T.cruzi & \\
\hline & & & $\mathrm{CCC}_{52316.1}$ & T,vivax & \\
\hline & & & CCC94421.1 & T.congolense & \\
\hline & & & XP_827894.1 & T. bruceibrucei & \\
\hline & & & ESL09806.1 & T.rangeli & \\
\hline & & & EAN78782.1 & T. bruceibrucei & \\
\hline 7. & $\begin{array}{l}\text { DNA topoisomerase } \\
\text { inhibitors } \\
\text { (Camptothecins, } \\
\text { Anthracyclines, } \\
\text { mitoxantrone and } \\
\text { Fluoroquinolones }\end{array}$ & DNA topoisomerases & DQ887563 & T.cruzi & $\begin{array}{l}\text { Aline et al. [77], } \\
\text { Dietmar and } \\
\text { Kevin [76] }\end{array}$ \\
\hline 8. & $\begin{array}{l}\text { Tubulin directed drugs } \\
\text { and Inhibition of lipid } \\
\text { synthesis }\end{array}$ & Tubulin & - & T. bruceibrucei & $\begin{array}{l}\text { Dietmar and } \\
\text { Kevin [76] }\end{array}$ \\
\hline
\end{tabular}

High-throughput screening of trypanosome RNA interference (RNAi) libraries is playing a significant role in understanding drug mechanism of action and up take [78]. However, it's becoming challenging to use such reduced-function approach to find out specific drug targets. Usually, drugs mode of action of antitrypanosomal drug is by inhibiting essential enzymes. Even without using drug, depleting the target can be life threatening. 
Theoretically, weak RNAi result in slowly growing cells with enhanced drug susceptibility. In normal circumstance, there are coincidences of the cells to die without adding drug for treatment. It implies that as a result of loss of function of one of cellular path way inside, there is an opportunity of the cell to be more susceptible to drug than the targeted pathway. Hence, gain-of-function approaches are the best choice for direct determination of the targets of drug of choice [79].

An experiment done by Alsford et al. [80], on five current HAT drugs for genome-scale RNA interference (RNAi) target sequencing (RIT-seq) screens in T. brucei were used, revealing the transporters, organelles, enzymes and metabolic pathways that function to facilitate anti-trypanosomal drug action. RIT-seq profiling identifies both known drug importers and the only known pro-drug activator, and links more than fifty additional genes to drug action [80].

A specific bloodstream stage invariant surface glycoprotein (ISG75) family mediates suramin uptake while the AP-1, lysosomal proteases and major lysosomal transmembrane protein and alsospermidine and $\mathrm{N}$ acetylglucosamine biosynthesis all contribute to suramin action [80]. If an antitrypanosomal drug inhibits the function of a single protein, then over expression of that protein or a fragment containing the drug binding site could result in reduced drug sensitivity. Due to loss of function of a single protein by antitrypanosomal drug, over expression of specific protein of interest or part of it with drug binding site is happened; consequently it leads to loss of drug sensitivity [81]. Glycolysis is perceived as a promising target for new drugs against parasitic trypanosomatid protozoa, because this pathway plays an essential role in their ATP supply. However, Bloodstream form T.theileri degrades glucose to acetate (47\%) and succinate (45\%) and, therefore, does not solely rely on glycolysis for ATP production. This trypanosomatid does not use amino acids for energy metabolism. Potential criteria to aid target selection are described below [9].

Table 5. Criteria for molecular targets developed $[82,83]$.

\begin{tabular}{|c|c|c|c|}
\hline Items & Green & Amber & Red \\
\hline Essentiality & $\begin{array}{l}\text { Genetic and chemical validation } \\
\text { that the target is essential for } \\
\text { survival of the organism }\end{array}$ & $\begin{array}{l}\text { Genetic or chemical } \\
\text { validation that the target is } \\
\text { essential for survival of the } \\
\text { organism }\end{array}$ & $\begin{array}{l}\text { No or weak genetic or } \\
\text { chemical validation that the } \\
\text { target is essential for } \\
\text { survival of the organism }\end{array}$ \\
\hline Druggability & $\begin{array}{l}\text { Drug-like, small molecule } \\
\text { inhibitors are known and there } \\
\text { is a druggable active site (clinical } \\
\text { activity within the target family) }\end{array}$ & $\begin{array}{l}\text { Drug-like, small molecule } \\
\text { inhibitors are known or the } \\
\text { active site is potentially } \\
\text { druggable }\end{array}$ & $\begin{array}{l}\text { No drug-like, small } \\
\text { molecule inhibitors are } \\
\text { known and the active site is } \\
\text { not druggable }\end{array}$ \\
\hline Assayability & $\begin{array}{l}\text { Robust assay in plate format } \\
\text { amenable to high-throughput } \\
\text { screening developed and active } \\
\text { protein supply assured within } \\
\text { appropriate time-lines }\end{array}$ & $\begin{array}{l}\text { In vitro assay exists, } \\
\text { development into robust, } \\
\text { plate format feasible, but not } \\
\text { yet achieved }\end{array}$ & $\begin{array}{l}\text { No in vitro assay developed } \\
\text { and/ or significant } \\
\text { problems with protein } \\
\text { supply }\end{array}$ \\
\hline Resistance potential & $\begin{array}{l}\text { Target has no known isoforms } \\
\text { within the same species and is } \\
\text { not subject to escape from } \\
\text { inhibition }\end{array}$ & $\begin{array}{l}\text { Target has isoforms within } \\
\text { same species or may be } \\
\text { subject to escape from } \\
\text { inhibition. }\end{array}$ & $\begin{array}{l}\text { Target has multiple gene } \\
\text { copies or isoforms within } \\
\text { same species and is subject } \\
\text { to escape from inhibition }\end{array}$ \\
\hline Toxicity potential & $\begin{array}{l}\text { No human homologue of the } \\
\text { target present, or the human } \\
\text { homologue is known to be non- } \\
\text { essential and inhibition of this } \\
\text { shows no effect on the human } \\
\text { host }\end{array}$ & $\begin{array}{l}\text { Human homologue of the } \\
\text { target is present, but } \\
\text { evidence (structural or } \\
\text { chemical) that selective } \\
\text { inhibition is possible }\end{array}$ & $\begin{array}{l}\text { Human homologue of the } \\
\text { target is present and little } \\
\text { or no evidence (structural } \\
\text { or chemical) that selective } \\
\text { inhibition is possible } \\
\text { Structure }\end{array}$ \\
\hline
\end{tabular}

Structure without ligand available and/or poor resolution $(>2 \cdot 3 \AA$ 号 or

Ligand-bound structure of Structural targetor ligand in closely related opportunity to build a good information homologue available at high resolution $(<2 \cdot 3 \AA)$ homology model (high sequence homology to homologue)

Adopted from Gilbert [9]. 
Table 6. Primers for T.theileri.

\begin{tabular}{cll}
\hline & Primer (forward and reverse) & Purpose \\
\hline 1 & $\begin{array}{l}\text { Tth625a (5'-CCG CTG GAG CTA AGA ATA GA-3') and } \\
\text { Tth625b (5'-AAT TGC ATA AAC ACA GCT CCC-3') }\end{array}$ & $\begin{array}{l}\text { For species-specific PCR amplification } \\
\text { (Tth625-PCR) }\end{array}$ \\
\hline \multirow{2}{*}{$\begin{array}{l}\text { Forward primer 18STnF2 (5'-CAA CGA TGA CAC CCA TGA ATT GGG GA-3') and } \\
\text { Reverse primer 18STnR3 (5'-TGC GCG ACC AAT AAT TGC AAT AC-3') }\end{array}$} & $\begin{array}{l}\text { The full length 18S ribosomal DNA } \\
\text { sequence Analysis }\end{array}$ \\
\hline & $\begin{array}{l}\text { Kinl reverse (5'- GCG TTC AAA GAT TGG GCA AT-3') and } \\
\text { Kin2 forward (5'-CGC CCG AAA GTT CAC C-3') }\end{array}$ & $\begin{array}{l}\text { For single PCR amplification to anneal } \\
\text { internal transcribed spacer of ribosomal } \\
\text { genes (ITS) sequence }\end{array}$ \\
\hline Source: Lee et al. [3], Rodrigues et al. [16] and Geysen et al. [43]
\end{tabular}

\section{Trypanosome genomics}

Two complementary approaches are being followed insequencing the trypanosome genome: genomic DNAsequencing and expressed sequence tag (EST) sequencing.Initial data emerging from the T. brucei shotgun genomesequence indicate that the overall sequence organizationof chromosomes is distinct from that of other highe reukaryotic organisms. For example, trypanosome genesare very tightly packed on chromosomes, which mightexplain in part the high incidence of alternative splicing ofpre-mRNAs and the generation of polycistronic RNAs. The transcripts appear to be unidirectional over long stretchesof the chromosomes [84].

The availability of genome sequence data has facilitated the development of high-throughput genetic screening approaches in microbial pathogens. In the African trypanosome, T.brucei, genome-scale RNA interference screens have proven particularly effective in this regard. These allow for identification of the genes that contribute to a pathway or mechanisms of interest. The approach has been used to assess loss-of-fitness, revealing the genes and proteins required for parasite viability and growth. Consequently, the results from these screens predict essential and dispensable genes which facilitate drug target prioritization efforts. The approach has also been used to assess resistance to anti-trypanosomal drugs, revealing the genes and proteins that facilitate drug uptake and action. These outputs also highlight likely mechanisms underlying clinically relevant drug resistance [85].

\section{CONCLUSION AND RECOMMENDATIONS}

Though T.theileri is nonpathogenic naturally, but it can cause illness to stressed cattle. Moreover, little is known about the parasite so far. However, since recently, it has become area of interest by considering it as a tool and vector to treat the pathogenic microorganisms; particularly protozoan parasites. T.theiler grows successfully in vitro in SDM 79 at $26^{\circ} \mathrm{C}$. The growth pattern, viability and its response for pentamidine can be checked through resazurin assay. The parasite (T.theileri), is confirmed using PCR amplification by species specific primers. Furthermore, the BLAST and MSA with common antitrypanosome target sequences. Subsequently, there is no significant similarity both at DNA and protein level with T. theileri unlike the antitrypanosome targets from pathogenic Trypanosomes. There is a chance to not to isolate the parasite immediately as a result of low parasitemia naturally. Hence, most of the isolation of T.theileri from natural infection was not confirmed purposively. Rather, it has been found during unexpectedly time. It can be isolated while researchers were doing for other objectives. For example, during macrophage culture, Total leukocyte and differential counts, PCV, while studying Bovine leukemia virus (BLV) from lymphocyte cultures of cows infected with it.

\section{Competing interests}

The author declares that there are no competing interests.

\section{REFERENCES}

1. Mott GA, Wilson R, Fernando A, Robinson A, MacGregor P, Kennedy D, Schaap D, Matthews JB, Matthews KR. Targeting cattle-borne zoonoses and cattle pathogens using a novel trypanosomatid-based delivery system. PLoS Pathogens. 2011; 7(10):e1002340. https://doi.org/10.1371/journal.ppat.1002340, Google Scholar

2. Verloo D, Brandt J, Van Meirvenne N, Büscher P. Comparative in vitro isolation of Trypanosoma theileri from cattle in Belgium. Veterinary Parasitology. 2000; 89(1-2):129-32. https://doi.org/10.1016/S0304-4017(00)00191-6, Google Scholar

3. Lee YF, Cheng CC, Chen JS, Lin NN, Hung YW, Wang JM, Tu WC, Tung KC, Chiu YT. Evidence of intracellular stages in Trypanosoma (Megatrypanum) theileri in non-phagocytic mammalian cells. Veterinary parasitology. 2013; 191(3-4):228-39.. https://doi.org/10.1016/ j.vetpar.2012.08.027, Google Scholar 
4. Hoare CA. The trypanosomes of mammals. A zoological monograph. Blackwell Scientific Publications, Oxford, 1972;pp.21-24. $\underline{\text { CAB }}$ Direct, Google Scholar

5. Latif $\mathrm{AA}$, Bakheit $\mathrm{MA}$, Mohamed $\mathrm{AE}$, Zweygarth E. High infection rates of the tick Hyalomma anatolicum anatolicum with Trypanosoma theileri. Onderstepoort Journal of Veterinary Research. 2004; 71(4):251-6. Direct Link, Google Scholar

6. Leach, T. M., \& Roberts, C. J. (1981). Trypanosoma theileri. Africa, (1972), 91-147.

7. Kolasinska-Zwierz P, Down T, Latorre I, Liu T, Liu XS, Ahringer J. Differential chromatin marking of introns and expressed exons by H3K36me3. Nat Genet. 2009; 41:376-381. Europe PMC free article, Abstract, Google Scholar

8. Aerts D, Truc P, Penchenier L, Claes Y, Le Ray D. A kit for in vitro isolation of trypanosomes in the field: first trial with sleeping sickness patients in the Congo Republic. Transactions of the Royal Society of Tropical Medicine and Hygiene. 1992 Jul 1;86(4):394-5. https://doi.org/10.1016/0035-9203(92)90234-4, Google Scholar

9. Gilbert IH. Target-based drug discovery for human African trypanosomiasis: selection of molecular target and chemical matter. Parasitology. 2014 Jan;141(1):28-36. https://doi.org/10.1017/S0031182013001017, Google Scholar

10. Shapiro TA, Englund PT. Selective cleavage of kinetoplast DNA minicircles promoted by antitrypanosomal drugs. Proceedings of the National Academy of Sciences. 1990 Feb 1;87(3):950-4. https://doi.org/10.1073/pnas.87.3.950, Google Scholar

11. Ekins S, Mestres J, Testa B. In silico pharmacology for drug discovery: methods for virtual ligand screening and profiling. British journal of pharmacology. 2007 Sep;152(1):9-20.. https://doi.org/10.1038/sj.bjp.0707305 , Google Scholar

12. Fatumo, S., Adebiyi, M., and Adebiyi, E. In Silico Models for Drug Discovery. (M. Lill, Ed.), In Silico Models for Drug Discovery, $2013 ;$ (Vol. 993). https://doi.org/10.1007/978-1-62703-342-8, ZLibrary Book

13. Amaro RE, Schnaufer A, Interthal H, Hol W, Stuart KD, McCammon JA. Discovery of drug-like inhibitors of an essential RNA-editing ligase in Trypanosoma brucei. Proceedings of the National Academy of Sciences. 2008 Nov 11;105(45):17278-83. https://doi.org/10.1073/pnas.0805820105, Google Scholar

14. Alonso-Padilla J, Rodríguez A. High throughput screening for anti-trypanosoma cruzi drug discovery. PLoS Negl Trop Dis. 2014 Dec 4;8(12):e3259. https://doi.org/10.1371/journal.pntd.0003259, Google Scholar

15. Agbo EC, Majiwa PA, Büscher P, Claassen E, te Pas MF. Trypanosoma brucei genomics and the challenge of identifying drug and vaccine targets. TRENDS in Microbiology. 2003 Jul 1;11(7):322-9.. https://doi.org/10.1016/Sog66-842X(03)00151-3 , Google Scholar

16. Rodrigues AC, Paiva F, Campaner M, Stevens JR, Noyes HA, Teixeira MM. Phylogeny of Trypanosoma (Megatrypanum) theileri and related trypanosomes reveals lineages of isolates associated with artiodactyl hosts diverging on SSU and ITS ribosomal sequences. Parasitology. 2006 Feb;132(2):215-24.. https://doi.org/10. 1017/S0031182005008929 , Google Scholar

17. Rodrigues AC, Garcia HA, Batista JS, Minervino AH, Góes-Cavalcante G, Da Silva FM, Ferreira RC, Campaner M, Paiva F, Teixeira MM. Characterization of spliced leader genes of Trypanosoma (Megatrypanum) theileri: phylogeographical analysis of Brazilian isolates from cattle supports spatial clustering of genotypes and parity with ribosomal markers. Parasitology. 2010;137(1):111. https://doi.org/10.1017/S0031182009991053, Google Scholar

18. Garcia HA, Kamyingkird K, Rodrigues AC, Jittapalapong S, Teixeira MM, Desquesnes M. High genetic diversity in field isolates of Trypanosoma theileri assessed by analysis of cathepsin L-like sequences disclosed multiple and new genotypes infecting cattle in Thailand. Veterinary parasitology. 2011 Aug 25;180(3-4):363-7. https://doi.org/10.1016/j.vetpar.2011.03.017, Google Scholar

19. Lee YF, Cheng CC, Lin NN, Liu SA, Tung KC, Chiu YT. Isolation of Trypanosoma (Megatrypanum) theileri from dairy cattle in Taiwan. Journal of Veterinary Medical Science. 2010;72(4):417-24. https://doi.org/10.1292/jvms.09-0343 , Google Scholar

20. Fraga J, Fernández-Calienes A, Montalvo AM, Maes I, Deborggraeve S, Büscher P, Dujardin JC, Van der Auwera G. Phylogenetic analysis of the Trypanosoma genus based on the heat-shock protein 70 gene. Infection, Genetics and Evolution. 2016 Sep 1;43:165-72.. https://doi.org/10. 1016/j. meegid.2016.05.016, Google Scholar

21. Saldarriaga OA, Velásquez JI, Ossa JE, Rugeles MT. Standardization of bovine macrophage monolayers and isolation and culture of trypanosomes. Memórias do Instituto Oswaldo Cruz. 2003 Mar;98(2):269-71. https://doi.org/10.1590/S0074-02762003000200017 , Google Scholar

22. Baldacchino F, Desquesnes M, Mihok S, Foil LD, Duvallet G, Jittapalapong S. Tabanids: neglected subjects of research, but important vectors of disease agents!. Infection, Genetics and Evolution. 2014 Dec 1;28:596-615. https://doi.org/10.1016/j.meegid.2014.03.029 , Google Scholar

23. Morzaria SP, Latif AA, Jongejan FR, Walker AR. Transmission of a Trypanosoma sp. to cattle by the tick Hyalomma anatolicum anatolicum. Veterinary Parasitology. 1986 Jan 1;19(1-2):13-21. https://doi.org/10.1016/0304-4017(86)90026-9, Google Scholar

24. Martins JR, Leite RC, Doyle RL. Tripanosomatídeos similares a Trypanosoma theileri no carrapato dos bovinos Boophilus microplus. Revista Brasileira de Parasitologia Veterinária. 2008 Jun;17(2):113-4. https://doi.org/10.1590/S1984-29612008000200010 ， Google Scholar

25. Bose R and Heister NC. Development of Trypanosoma (Megatrypanum) theileri in tabanids. The Journal of Eukaryotic Microbiology, 1993; 40, 788-792. doi: https://doi.org/10.1111/j.1550-7408.1993.tb04475, Google Scholar

26. Böse R, Friedhoff KT, Olbrich S, Büscher G, Domeyer I. Transmission of Trypanosoma theileri to cattle by Tabanidae. Parasitology research. 1987 Sep 1;73(5):421-4. https://doi.org/10.1007/BF00538199, Google Scholar

27. Braun U, Rogg E, Walser M, Nehrbass D, Guscetti F, Mathis A, Deplazes P. Trypanosoma theileri in the cerebrospinal fluid and brain of a heifer with suppurative meningoencephalitis. Vet. Rec., 2002; 150, 18-19. http://dx.doi.org/10.1136/vr.150.1.18, Google Scholar

28. Griebel PJ, Gajadhar AA, Babiuk LA, Allen JR. Trypanosoma thei- leri associated with T-lymphocytes isolated from a latently infected cow. The Journal of protozoology. 1989; 36, 415-421. Google Scholar

29. Suganuma K, Kondoh D, Sivakumar T, Mizushima D, Thekisoe OM, Yokoyama N, Inoue N. Molecular characterization of a new Trypanosoma (Megatrypanum) theileri isolate supports the two main phylogenetic lineages of this species in Japanese cattle. Parasitology research. 2019 Jun 1;118(6):1927-35. https://doi.org/10.1007/s00436-019-06313-x , Google Scholar

30. Shastri UV, Deshpande PD. Hyalomma anatolicum anatolicum (Koch, 1844) as a possible vector for transmission of Trypanosoma theileri, Laveran, 1902 in cattle. Veterinary Parasitology. 1981 Dec 1;9(2):151-5. https://doi.org/10.1016/0304-4017(81)90034-0 , Google $\underline{\text { Scholar }}$

31. Lukes, J. Trypanosoma Gruby 1843. Version 02 January 2009 (under construction). 
http://tolweb.org/Trypanosoma/98034/2009.01.02in The Tree of Life Web Project, Google Scholar http://tolweb.org/http://tolweb.org/Trypanosoma/98034

32. Townsend J, Duffus WP. Trypanosoma theileri: antibody-dependent killing by purified populations of bovine leucocytes. Clinical and Experimental Immunology. 1982 May;48(2):289. Google Scholar

33. Ward WH, Hill MW, Mazlin ID, Foster CK. Anaemia associated with a high parasitaemia of Trypanosoma theileri in a dairy cow. Australian veterinary journal. 1984 Oct;61(10):324. https://doi.org/10.1111/j.1751-0813.1984.tbo7140.x ， Google Scholar

34. Seifi HA. Clinical trypanosomosis due to Trypanosoma theileri in a cow in Iran. Tropical animal health and production. 1995 Jun 1;27(2):93-4. DOI: https://doi.org/10.1007/bfo2236319 , PMID: 7652945, Google Scholar

35. Villa A, Gutierrez C, Gracia E, Moreno B, Chacón G, Sanz PV, Büscher P, Touratier L. Presence of Trypanosoma theileri in Spanish cattle. Annals of the New York Academy of Sciences. 2008 Dec;1149(1):352-4. DOI: http://dx.doi.org/10.1196/annals.1428.016 , Google $\underline{\text { Scholar }}$

36. Delespaux V, de Koning HP. Drugs and drug resistance in African trypanosomiasis. Drug resistance updates. 2007 Feb 1;10(1-2):30-50. doi: https://doi.org/10.1016/j. drup.2007.02.004 , Google Scholar

37. Desquesnes M, McLaughlin G, Zoungrana A, Dávila AM. Detection and identification of Trypanosoma of African livestock through a single PCR based on internal transcribed spacer 1 of rDNA. International Journal for Parasitology. 2001 May 1;31(5-6):610-4. https://doi.org/10.1016/S0020-7519(01)00161-8, Google Scholar

38. Herbert, I. V. Trypanosoma theileri, Laveran, 1902. A cosmopolitan parasite of cattle. Vet. Bull., 1964; 34: 563- 570. Google Scholar

39. Splitter, E. J., \& Soulsby, E. J. Isolation and continuous cultivation of Trypanosoma theileri in media containing tissue culture fluids. Experimental Parasitology, 1967; 21(2), 137-48. Retrieved from http://www.ncbi.nlm.nih.gov/pubmed/4169719 , https://doi.org/10.1016/0014-4894(67)90075-6, Google Scholar

40. Wells, E.A. Subgenus Megatrypanum W.H.R. Lumsden, D.A. Evans. Biology of the Kinetoplastida, Academic Press, London, 1976; pp. 257-275. Google Scholar

41. Hirumi,H.,Hirumi,K., Doyle,J.J.,Cross,G.A.M. In vitro cloning of animal infective bloodstream forms of Trypanosoma brucei.Parasitology, 1980; 80:371-382. Google Scholar

42. Deborggraeve S, Buscher P. Recent progress in molecular diagnosis of sleeping sickness.Expert Rev Mol Diagn, 2012; 12:719-730. https://doi.org/10.1586/erm.12.72, Google Scholar

43. Geysen D, Delespaux V, Geerts S. PCR-RFLP using Ssu-rDNA amplification as an easy method for species-specific diagnosis of Trypanosoma species in cattle. Vet Parasitol., 2003; 110:171-180. https://doi.org/10.1016/S0304-4017(02)00313-8, Google Scholar

44. Njiru Z, Constantine C, Guya S The use of ITS1 rDNA PCR in detecting pathogenic African trypanosomes. Parasitol Res., 2005;95:186192. Google Scholar

45. Njiru ZK. Loop-mediated isothermal amplification technology: towards point of care diagnostics. PLoS Negl Trop Dis., $2012 ; 6: 1572$. https://doi.org/10.1371/journal.pntd.0001572, Google Scholar

46. Notomi T, Okayama H, Masubuchi H. Loop-mediated isothermal amplification of DNA. Nucleic Acids Res., 2000; $28: 7-9$. https://doi.org/10.1093/nar/28.12.e63, Google Scholar

47. Cash, P. Characterisation of bacterial proteomes by two-dimensional electrophoresis. Anal Chim Acta, 1998; 372: 121-145. https://doi.org/10.1016/S0003-2670(98)00346-8, Google Scholar

48. Ong, S.E., and Pandey, A. An evaluation of the use of two-dimensional gel electrophoresis in proteomics. Biomol Eng., 2001; 18: 195-205 http://www. ncbi.nlm.nih. gov/ entrez/ query.fcgi? $\mathrm{cmd}=$ Retrieve\&db= PubMed\&dopt=Citati on\&list_uids=11911086. https://doi.org/10.1016/S1389-0344(01)00095-8, Google Scholar

49. Görg, A., Postel, W., Günther, S., Weser, J. Improved horizontal two-dimensional electrophoresis with hybrid isoelectric focusing in immobilized $\mathrm{pH}$ gradients in the first dimension and laying-on transfer to the second dimension. Electrophoresis, 1985; 6:599-604 https://doi.org/10.1002/elps.1150061206, Google Scholar

50. Scopes, R.K. Protein purification: Principles and practice, $2^{\text {nd }}$ Ed., 1987;Chapter 2: Making an Extract, Springer Verlag, NY. Google $\underline{\text { Scholar }}$

51. Klose, J. Protein mapping by combined isoelectric focusing and electrophoresis of mouse tissues. A novel approach to testing for induced point mutation in mammals. Humangenetik, 1975; 26:231-243. Google Scholar

52. Roy Wollman, and Nico Stuurman. High throughput microscopy: from raw images to discoveries. Journal of Cell Science, 2007; 120: 3715-3722 Published by The Company of Biologist. doi: 10.1242/jcs.013623, Google Scholar

53. V Starkuviene and R Pepperkok. The potential of high-content high-throughput microscopy in drug discover. British Journal of Pharmacology, 2007; 152:62-71. https://doi.org/10.1038/sj.bjp.0707346, Google Scholar

54. Ellenberg J, Pepperkok R .High throughput fluorescence microscopy for systems biology. Nat Rev Mol Cell Biol., 2006; 7: 690-696. Google Scholar

55. Lippincott-Schwartz J, Snapp E, Kenworthy A. Studying protein dynamics in living cells. Nat Rev Mol Cell Biol., $2001 ; 2: 444-456$. Google Scholar

56. Sonnichsen B, Koski LB, Walsh A, Marschall P, Neumann B, Brehm M. Full- genome RNAi profiling of early embryogenesis in Caenorhabditis elegans. Nature, 2005; 436: 861-865. Google Scholar

57. Fairlamb AH. Chemotherapy of human African trypanosomiasis: current and future prospects. Trends Parasitol., 2003; 19:488-494. https://doi.org/10.1016/j.pt.2003.09.002, Google Scholar

58. Naula, C., Parsons, M., and Mottram, J.C. Protein kinases as drug targets in trypanosomes and Leishmania. Biochim Biophys Acta Proteins Proteomics., 2005; 1754: 151-159. https://doi.org/10.1016/j.bbapap.2005.08.018, Google Scholar

59. Babokhov, P., Sanyaolu, A. O., Oyibo, W. A., Fagbenro-Beyioku, A. F., and Iriemenam, N. C. A current analysis of chemotherapy strategies for the treatment of human African trypanosomiasis. Pathog. Glob. Health, 2013 ; 107: $242-252$. https://doi.org/10.1179/2047773213Y.0000000105, Google Scholar

6o. Wrry, M. Antimierobial Agents Drugs used in the treatment of sleeping sickness ( human African trypanosomiasis: HAT ). Int J Antimicro Ag., 1994; 4: 227-238. https://doi.org/10.1016/0924-8579(94)90012-4, Google Scholar 
61. Garcia-Salcedo, J. A., Unciti-Broceta, J. D., Valverde-Pozo, J., \& Soriano, M. New Approaches to Overcome Transport Related Drug Resistance in Trypanosomatid Parasites. Frontiers in Pharmacology, 2016; 7 (September), 1-14. https://doi.org/10.3389/fphar.2016.00351 , Google Scholar

62. Wilkinson, S. R., \& Kelly, J. M. Trypanocidal drugs: mechanisms, resistance and new targets. Expert Reviews in Molecular Medicine, 2009; 11 (October 2009), e31. https://doi.org/10.1017/S1462399409001252, Google Scholar

63. Cynthia M Kahn; Scott Line; Merck and Co. A clinical guide to the care of domestic, laboratory, and zoo animals that contains information on nutrition, physiology, medical disorders, and methods of treatment, 2010; $10^{\text {th }}$ ed, Whitehouse Station. , Google Scholar

64. Fairlamb, A.H., Henderson, G.B., and Cerami, A. Trypanothione is the primary target for arsenical drugs against African trypanosomes. Proc. Natl. Acad. Sci. U.S.A., 1989; 86, 2607- 2611. , Google Scholar

65. Grishin, N.V., Osterman, A.L., Brooks, H.B., Phillips, M.A., and Goldsmith, E.J. X-ray structure of ornithine decarboxylase from Trypanosoma brucei: the native structure and the structure in complex with alphadifluoromethylornithine. Biochemistry, 1999; 38: 15174- 15184. https://doi.org/10.1021/big915115, Google Scholar

66. Boibessot, I., Turner, C.M., Watson, D.G., Goldie, E., Connel, G., McIntosh, A., Grant, M.H., and Skellern, G.G. Metabolism and distribution of phenanthridine trypanocides in Trypanosoma brucei. Acta Trop., 2002; 84, 219-228. https://doi.org/10.1016/Sooo1706X(02)00188-2, Google Scholar

67. Baker, N., Koning, H. P. De, Mäser, P., \& Horn, D. Europe PMC Funders Group Drug resistance in African trypanosomiasis: the melarsoprol and pentamidine story Chemotherapy against African trypanosomiasis Europe PMC Funders Author Manuscripts The diamidines, 2013; 29(3). https://doi.org/10.1016/j.pt.2012.12.005. , Google Scholar

68. Lv, W., Xu, Y., Guo, Y., Yu, Z., Feng, G., Liu, P. The drug target genes show higher evolutionary conservation than non-target genes. Oncotarget, 2016; 7: 4961-71 http://www.pubmedcentral.nih.gov/articlerender.fcgi?artid=4826257\&tool=pmcentrez\&re ndertype=abstract. doi: 10.18632/oncotarget.6755, Google Scholar

69. Wishart DS, Knox C, Guo AC, Shrivastava S, Hassanali M, Stothard P, Chang Z, Woolsey J. DrugBank: a comprehensive resource for in silico drug discovery and exploration. Nucleic Acids Res.,2006;34:D668-672. https://doi.org/10.1093/nar/gkjo67, Google Scholar

70. Agüero F, Al-Lazikani B, Aslett M, Berriman M, Buckner FS, Campbell RK, Carmona S, Carruthers IM, Chan AE, Chen F. Genomic-scale prioritization of drug targets: the TDR Targets database. Nature Reviews Drug Discovery, 2008; 7: 900-907. , Google Scholar

71. Zhu F, Shi Z, Qin C, Tao L, Liu X, Xu F, Zhang L, Song Y, Liu X, Zhang J. Therapeutic target database update 2012: a resource for facilitating target-oriented drug discovery. Nucleic Acids Res.:gkr., 2011; 797. https://doi.org/10.1093/nar/gkr797, Google Scholar

72. Gibson, W.C. and Stevens, J. Genetic exchange in the Trypanosomatidae. Adv. Parasitol. , 1999; 43: 1-45. https://doi.org/10.1016/Soo65308X(08)60240-7, Google Scholar

73. Begolo, D., Erben, E., and Clayton, C. Drug target identification using a trypanosome overexpression library. Antimicrob Agents Chemother,2014; 58: 6260-6264. DOI: 10.1128/AAC.03338-14, Google Scholar

74. Owino VA, Limoh MK, Masiga, DK. Cloning and analysis of trans-splicing factors in Trypanosoma brucei. Proceedings of Egerton University research Week. Egerton University Press. , 2006;pp. 210 - 222. http://hdl.handle.net/123456789/871, Google Scholar

75. Rory,E. M., Linda, T., Robert, N.P., Roy, J., Peter, N.,John, D. E.and Theresa, H.T.CA trypanosome oligopeptidase as a target for the trypanocidal agents pentamidine, diminazene and suramin. Federation of European Biochemical Societies(FEBS) Letters, 1998; 433: 251-256. https://doi.org/10.1016/Soo14-5793(98)oog14-4, Google Scholar

76. Dietmar Steverding and Kevin M Tyler. Novel antitrypanosomal agents. Expert Opin. Investig. Drugs, 2005; 14(8):939-955. https://doi.org/10.1517/13543784.14.8.939, Google Scholar

77. Aline, A Z, Danielle, PC. , Marina, C.P. , Maia, W S. and Maria, C M. Effect of topoisomerase inhibitors and DNA-binding drugs on the cell proliferation and ultrastructure of Trypanosoma cruzi.International Journal of Antimicrobial Agents, 2011 ; $449-456$. https://doi.org/10.1016/j.ijantimicag.2010.11.031, Google Scholar

78. Alsford S, Turner DJ, Obado SO, Sanchez-Flores A, Glover L, Berriman M, Hertz-Fowler C, Horn D. High-throughput phenotyping using parallel sequencing of RNA interference targets in the African trypanosome. Genome Res., 2011; 21:915-924. http://dx.doi.org/10.1101/gr. 115089.110. , Google Scholar

79. Alsford S, Kelly JM, Baker N, Horn D. Genetic dissection of drug resistance in trypanosomes. Parasitology, 2013; 140:14781491. https://doi.org/10.1017/So03118201300022X, Google Scholar

80. Alsford, Sam, Sabine Eckert, Nicola Baker, Lucy Glover, Alejandro Sanchez-Flores, Ka Fai Leung, Daniel J. Turner, Mark C. Field, Matthew Berriman, and David Horn. High-throughput decoding of anti-trypanosomal drug efficacy and resistance.Nature, 2012 ; 482(7384): 232-236. doi:10.1038/nature10771. , Google Scholar

81. Ranade RM, Gillespie JR, Shibata S, Verlinde CL, Fan E, Hol WG, Buckner FS. Induced resistance to methionyl-tRNA synthetase inhibitors in Trypanosoma brucei is due to overexpression of the target. Antimicrob. Agents Chemother, 2013; 57:3021-3028. http://dx.doi.org/10.1128/AAC.02578-12. , Google Scholar

82. Frearson J. A., Wyatt P. G., Gilbert I. H. and Fairlamb A. H. Target assessment for antiparasitic drug discovery. Trends in Parasitology, 2007; 23, 589-595 [PMC free article] [PubMed] https://doi.org/10.1016/j.pt.2007.08.019, Google Scholar

83. Wyatt P. G., Gilbert I. H., Read K. D. and Fairlamb A. H. Target validation: linking target and chemical properties to desired product profile. Current Topics in Medicinal Chemistry, 2011; 11, 1275-1283 [PMC free article] [PubMed] [Google Scholar].

84. El-Sayed, N.M. et al. The African trypanosome genome. Int. J. Parasitol., 2000; 30: 329-345. https://doi.org/10.1016/Soo207519(00)0o015-1, Google Scholar

85. Horn, D. High-throughput decoding of drug targets and drug resistance mechanisms in African trypanosomes. Parasitology, 2014; 141:77-82 http://www.ncbi.nlm.nih. gov/pubmed/ 23561654. https://doi.org/10.1017/So031182013000243, Google Scholar

86. Simpson AG, Stevens JR, Lukes J .The evolution and diversity of kinetoplastid flagellates. Trends Parasitol., 2006; 22:168-174. https://doi.org/10.1016/j.pt.2006.02.006, Google Scholar 